\title{
PENGARUH PRAKTEK GOOD CORPORATE GOVERNANCE TERHADAP KINERJA KEUANGAN PERUSAHAAN YANG MASUK DALAM PEMERINGKATAN CORPORATE GOVERNANCE PERCEPTION INDEX (CGPI)
}

\author{
Natrion, SE.,M.Ak \\ dan \\ Lam Minar \\ Fakultas Ekonomi Program Studi Akuntansi \\ Universitas Satya Negara Indonesia
}

\begin{abstract}
ABSTRAK
Penerapan untuk tata kelola perusahaan yang baik (Good Corporate Governance) dapat diartikan sebagai suatu proses yang digunakan oleh perusahaan untuk meningkatkan kualitas kinerja keuangan perusahaan. Kinerja keuangan merupakan pengakuan pendapatan dan pengaitan biaya menghasilkan angka laba yang lebih unggul dibandingkan arus kas untuk mengevaluasi kinerja keuangan. Pengakuan pendapatan memastikan bahwa semua pendapatan yang dihasilkan dalam suatu periode telah diakui. Dalam mengukur kinerja keuangan perusahaan yaitu dapat menggunakan Return of Equity (ROE) dan Net Profit Margin (NPM).

Tujuan dari penelitian ini adalah untuk mengetahui pengaruh penerapan good corporate governance (GCG) terhadap kinerja keuangan perusahaan. Variabel skor penerapan GCG digunakan sebagai indikator GCG, sedangkan Return on Equity (ROE) dan Net Profit Margin (NPM) digunakan sebagai indikator kinerja keuangan perusahaan.

Penelitian ini merupakan penelitian yang variabelnya bersifat kausalitas. Sampel penelitian ini adalah perusahaan yang masuk dalam pemeringkatan CGPI. Data yang digunakan bersifat pooling (data series dan cross sectional) dan diambil dari laporan CGPI dan laporan keuangan tahunan dari tahun 2009-2013. Pengujian hipotesis dilakukan dengan metode statistik melalui analisis regresi linear sederhana.

Hasil dari penelitian ini adalah praktek Good Corporate Governance berpengaruh positif terhadap ROE dan NPM.

Kata Kunci: Good Corporate Governance (GCG); Return of Equity (ROE); Net Profit Margin (NPM).
\end{abstract}




\begin{abstract}
The application of good corporate governance (GCG) can be defined as a process used by the company to improve the quality of the company's financial performance. The financial performance of the recognition of revenues and expenses linkage generate earnings figures are more superior than cash flow to evaluate financial performance. Revenue recognition to ensure that all income generated in the period has been recognized. In measuring the financial performance of companies that can use the Return on Equity (ROE) and Net Profit Margin (NPM).

The main objective of this research was to determine whether the application of good corporate governance $(G C G)$ positive effect on the company's financial performance. Variable score of GCG implementation is used as an indicator of good corporate governance, while Return on Equity (ROE) and Net Profit Margin (NPM) is used as an indicator of financial performance.

Variable used in this research is causal. The sample was companies included in the rating CGPI. The data used are pooling (data series and cross sectional) and taken from the CGPI report and annual financial statements of the years 2009-2013. Hypothesis testing is done by statistical methods through a simple linear regression analysis.

Results from this research are the practice of good corporate governance positive effect on ROE and NPM.
\end{abstract}

Keywords: Good Corporate Governance (GCG); Return of Equity (ROE); Net Profit Margin (NPM). 


\section{Latar Belakang}

\section{PENDAHULUAN}

Indonesia merasakan pentingnya good corporate governance setelah mengalami krisis pada tahun 1997 yang ditandai dengan reformasi di berbagai sektor di Indonesia. Saat itu sektor ekonomi yang memegang peranan dalam suatu negara menjadi lumpuh dan untuk menggerakkannya, Indonesia membutuhkan bantuan suntikan dana dari luar negeri. Kemudian hadirlah lembaga keuangan internasional IMF (International Monetary Fund) yang memberikan bantuan dana dengan mensyaratkan peningkatan tata kelola yang baik atau good governance di Indonesia. Dari pengalaman inilah pemerintah dan para pelaku bisnis merasakan pentingnya tata kelola yang baik (good governance). Selanjutnya disusunlah berbagai bentuk peraturan perundang-undangan, serta segala bentuk dokumentasi dan kelembagaan yang berhubungan dengan good governance yang diharapkan dapat membumikan praktik good governance di Indonesia agar menjadikan Indonesia makmur, sejahtera dan tahan dari segala bentuk krisis yang mengancam di masa yang akan datang. Demikian pula dengan good corporate governance, setelah krisis 1997 disusunlah berbagai dokumentasi, kebijakan dan peraturan terkait good corporate governance, serta dibentuknya lembaga-lembaga dan program-program yang mendorong penerapan good corporate governance di Indonesia.

Konsep corporate governance tersebut dapat didefinisikan sebagai serangkaian mekanisme yang mengarahkan dan mengendalikan suatu perusahaan agar operasional perusahaan berjalan sesuai dengan harapan para pemangku kepentingan (stakeholders). Selanjutnya good corporate governance dapat didefinisikan sebagai struktur, sistem, dan proses yang digunakan oleh organ-organ perusahaan sebagai upaya untuk memberikan nilai tambah perusahaan secara berkesinambungan dalam jangka panjang, dengan tetap memperhatikan kepentingan stakeholder lainnya, berlandaskan peraturan perundangan dan norma yang berlaku.

Perhatian investor terhadap good corporate governance sama besarnya dengan perhatian investor terhadap kinerja keuangan perusahaan. Good corporate governance juga berfungsi untuk menumbuhkan kepercayaan investor terhadap perusahaan. Penerapan good corporate governance akan mencegah kesalahan dalam pengambilan keputusan dan perbuatan menguntungkan diri sehingga secara langsung akan meningkatkan nilai perusahaan yang tercermin pada kinerja keuangan.

Kinerja keuangan merupakan pengakuan pendapatan dan pengaitan biaya menghasilkan angka laba yang lebih unggul dibandingkan arus kas untuk mengevaluasi kinerja keuangan. Pengakuan pendapatan memastikan bahwa semua pendapatan yang dihasilkan dalam suatu periode telah diakui. Pengaitan memastikan bahwa beban yang dicatat pada suatu periode hanya beban yang terkait dengan periode tersebut (Subramanyam dan Wild. 2008:101). Dalam mengukur kinerja keuangan perusahaan yaitu dapat menggunakan Return of Equity (ROE) dan Net Profit Margin (NPM).

Mamduh Hanafi (2004:42), menyatakan bahwa Return of Equity (ROE) mengukur kemampuan perusahaan menghasilkan laba bersih berdasarkan modal tertentu. Rasio ini merupakan ukuran profibilitas dilihat dari sudut pandang pemegang saham.

Dan Net Profit Margin (NPM) juga termasuk ke dalam rasio profitabilitas karena merupakan perbandingan antara laba bersih dengan penjualan. Rasio ini menggambarkan 
laba bersih perusahaan dibandingkan dengan penjualan. Semakin tinggi NPM akan semakin baik operasi perusahaan begitu juga sebaliknya apabila semakin rendah NPM maka operasi perusahaan kurang baik.

Penelitian mengenai good corporate governance dan kinerja keuangan perusahaan telah dilakukan beberapa peneliti sebelumnya. Penelitian yang dilakukan oleh Carina Hermanda (2010), menyimpulkan bahwa GCG mempunyai pengaruh positif dan signifikan terhadap kinerja keuangan (EVA) dan penelitian yang dilakukan oleh Like Monisa Wati (2012) menyimpulkan bahwa Good Corporate Governance mempengaruhi secara positif kinerja keuangan perusahaan (ROE dan NPM). Sedangkan pada penelitian yang dilakukan oleh Gabriela Cyntya Windah (2013), Tidak adanya pengaruh signifikan antara variabel independen GCG terhadap kinerja keuangan yang diukur dengan ROA dan Tobin's- $Q$, sedangkan jika diukur dengan ROE mempunyai pengaruh yang signifikan.

\section{Perumusan Masalah}

Berdasarkan latar belakang penelitian yang telah dikemukakan, maka penulis merumuskan masalah sebagai berikut:

1. Apakah praktek good corporate governance berpengaruh terhadap kinerja keuangan perusahaan yaitu Return of Equity (ROE) yang masuk dalam pemeringkatan Corporate Governance Perception Index (CGPI)?

2. Apakah praktek good corporate governance berpengaruh terhadap kinerja keuangan perusahaan yaitu Net Profit Margin (NPM) yang masuk dalam pemeringkatan Corporate Governance Perception Index (CGPI)?

\section{Batasan Masalah}

Dalam memfokuskan penelitian agar masalah yang diteliti memiliki ruang lingkup yang jelas, maka peneliti memberikan batasan masalah yaitu penelitian ini hanya menggunakan hasil skor pemeringkatan CGPI dalam penerapan Good Corporate Governance (GCG) yang diambil dari IICG dari tahun 2009-2013 serta ROE dan NPM yang bersumber dari laporan tahunan (annual report) perusahaan-perusahaan tersebut yang diambil dari Bursa Efek Indonesia periode tahun 2009-2013.

\section{LANDASAN TEORI}

\section{Pengertian Good Corporate Governance}

Tjager at. al. (2003) menyimpulkan bahwa good corporate governance - pada intinya - merupakan suatu sistem, proses dan perangkat peraturan yang mengatur hubungan antara berbagai pihak yang berkepentingan (stakeholders) terutama dalam arti sempit hubungan antara pemegang saham, dewan komisaris dan dewan direksi demi tercapainya tujuan organisasi. Good corporate governance dimaksudkan untuk mengatur hubungan ini dan mencegah terjadinya kesalahan-kesalahan (mistakes) signifikan dalam strategi korporasi dan untuk memastikan bahwa kesalahan-kesalahan yang terjadi dapat diperbaiki dengan segera.

Menurut CeBISS (2001) - Lembaga Independent Research \& Publication for Business Development - bahwa good corporate governance merupakan kelanjutan dari agency theory yang dalam tataran empirik kurang memadai untuk digunakan sebagai alat menyelenggarakan perusahaan modern di mana terdapat ciri yang menonjol terpisahnya 
kepemilikan dengan pengelolaan serta digunakannya dana pinjaman selain dana dari pesaham sehingga dibutuhkanlah good corporate governance.

Menurut Bank Dunia (World Bank), good corporate governance adalah sekumpulan hukum peraturan dan kaidah-kaidah yang wajib dipenuhi dan dapat mendorong kinerja sumber-sumber perusahaan untuk bekerja secara efisien, menghasilkan nilai ekonomi jangka panjang yang berkesinambungan bagi para pemegang saham maupun masyarakat sekitar secara keseluruhan.

Menurut Surat Keputusan Menteri Negara/Kepala Badan Penanaman Modal dan Pembinaan BUMN No. 23/M-PM.PBUMN/2000 tentang pengembangan praktek good corporate governance dalam Perusahaan Perseroan (Persero), menjelaskan bahwa good corporate governance adalah prinsip korporasi yang sehat yang perlu diterapkan dalam pengelolaan perusahaan yang dilaksanakan semata-mata demi menjaga kepentingan perusahaan dalam rangka mencapai maksud dan tujuan perusahaan.

The Indonesian Institute of Corporate Governance (IICG) mendefinisikan corporate governance sebagai proses dan struktur yang diterapkan dalam menjalankan perusahaan dengan tujuan utama untuk meningkatkan nilai pemegang saham dalam jangka panjang dengan tetap memperhatikan kepentingan stakeholders lainnya.

Berdasarkan kelompok definisi diatas, maka kesimpulan dari good corporate governance dapat didefinisikan sebagai sistem yang terdiri atas proses dan struktur (mekanisme) yang mengendalikan dan mengkoordinasikan berbagai partisipan dalam menjalankan bisnis perusahaan. Proses digunakan untuk mengarahkan dan mengelola aktivitas-aktivitas bisnis yang direncanakan dalam rangka mencapai tujuan perusahaan, menyelaraskan perilaku perusahaan dengan ekspektasi dari masyarakat, serta mempertahankan akuntabilitas perusahaan kepada pemegang saham. Struktur akan menspesifikasikan pendistribusian hak-hak dan tanggung jawab diantara berbagai partisipan dalam organisasi seperti dewan komisaris, manajer, pemegang saham, serta pemangku kepentingan lainnya, dan menjelaskan aturan-aturan maupun prosedur-prosedur untuk pengambilan keputusan dalam hubungan perusahaan.

Berbagai peristiwa dalam dasawarsa terakhir ini telah menjadikan corporate governance menjadi isu penting di kalangan eksekutif, Non Government Organization (NGO), konsultan korporasi, akademisi, dan pembuat kebijakan (pemerintah) di berbagai belahan dunia. Isu yang terkait dengan corporate governance seperti insider trading, transparansi, akuntabilitas, independensi, etika bisnis, tanggung jawab sosial, dan perlindungan investor telah menjadi ungkapan lazim dibicarakan di kalangan pelaku usaha. Corporate governance juga telah menjadi salah satu isu penting bagi pelaku usaha di Indonesia. Sentralisasi isu corporate governance dilatarbelakangi permasalahan yang terkait dengan trend di industri pasar modal, korporasi, pasar audit, tuntutan akan transparansi dan independensi, dan krisis financial Asia. Penerapan prinsip-prinsip GCG, yang didukung dengan regulasi yang memadai, akan mencegah berbagai bentuk overstated, ketidakjujuran dalam financial disclosure yang merugikan stakeholders (Daniri, 2005).

The Indonesian Institute for Corporate Governance (IICG) berdiri pada tanggal 2 Juni 2000 atas prakarsa Masyarakat Transparansi Indonesia (MTI), praktisi dan profesional, serta tokoh masyarakat yang memiliki visi dan kepedulian terhadap masa depan Indonesia yang lebih baik. Tujuan membentuk IICG adalah untuk memasyarakatkan konsep corporate governance dan manfaat penerapan prinsi-prinsip GCG seluas-luasnya dalam rangka 
mendorong terciptanya dunia usaha Indonesia yang beretika dan bermartabat. Wujud kontribusi IICG tersebut dicanangkan dalam empat kegiatan utama, yaitu: (1) Penelitian dan Pemeringkatan, (2) Pendidikan dan Pelatihan, (3) Publikasi dan Promosi, serta (4) Penilaian dan Pengembangan.

Salah satu program yang terus menerus dilaksanakan IICG sejak tahun 2001 hingga sekarang adalah Corporate Governance Perception Index (CGPI) yaitu program riset dan pemeringkatan penerapan Good Corporate Governance (GCG) pada perusahaan-perusahaan di Indonesia melalui perancangan riset yang mendorong perusahaan meningkatkan kualitas penerapan konsep Corporate Governance (CG) dengan melaksanakan evaluasi dan benchmarking sebagai upaya perbaikan yang berkesinambungan (continuous improvement). CGPI telah diselenggarakan oleh IICG bekerjasama dengan Majalah SWA sebagai program rutin tahunan sejak tahun 2001 sebagai bentuk penghargaan terhadap inisiatif dan hasil upaya perusahaan dalam mewujudkan bisnis yang beretika dan bermartabat. Kepesertaan CGPI bersifat sukarela dan melibatkan peran aktif perusahaan bersama seluruh stakeholders dalam memenuhi tahapan pelaksanaan program CGPI, dan hal tersebut menunjukkan komitmen bersama dalam memasyarakatkan GCG, karena program CGPI berupaya mendorong dan menuntut perusahaan peserta untuk melakukan perbaikan atau peningkatan praktik GCG di lingkungannya.

Metodologi penilaian pada setiap kegiatan riset dan pemeringkatan CGPI dikembangkan oleh para peneliti senior dengan acuan berbagai referensi dari Indonesia maupun Internasional yang terkait dengan GCG berdasarkan perspektif stakeholders sebagai alat ukur, dan disesuaikan dengan tema sentral yang ditetapkan. Penilaian yang dilakukan terhadap implementasi GCG secara terbatas mencakup aspek komitmen dan aturan main organ perusahaan, sedangkan implementasi GCG secara luas mencakup aspek komitmen dan hubungan antara perusahaan dengan stakeholders. Cara pandang seperti ini akan memperluas orientasi dan cakupan implementasi GCG yang memiliki konsekuensi pada waktu dan upaya yang dibutuhkan dalam proses mewujudkan praktik terbaik.

\section{Pengertian Kinerja Keuangan Perusahaan}

Kinerja rasio keuangan merupakan alat ukur yang digunakan perusahaan untuk menganalisis laporan keuangan. Rasio menggambarkan suatu hubungan atau pertimbangan antara suatu jumlah tertentu dengan jumlah yang lain. Dengan menggunakan alat analisa berupa rasio keuangan dapat menjelaskan dan memberikan gambaran kepada penganalisa tentang baik atau buruknya keadaan atau posisi keuangan suatu perusahaan dari suatu periode ke periode berikutnya (Yunanto, 2008).

Laporan keuangan bersifat historis, menyeluruh dan merupakan suatu progress report, yang merupakan hasil kombinasi antara fakta yang tercatat, prinsip-prinsip dan anggapan serta konvesi atau kebiasaan-kebiasaan dalam akuntansi dan pendapat pribadi (personal judgement) (Munawir, 2008).

\section{Pengertian Return of Equity (ROE)}

Return On Equity (ROE) menurut Sawir (2005:20) merupakan sebuah rasio yang sering dipergunakan oleh pemegang saham untuk menilai kinerja perusahaan yang bersangkutan. ROE mengukur besarnya tingkat pengembalian modal dari perusahaan. 
Menurut Irham Fahmi (2012:99), Return of Equity (ROE) adalah suatu perhitungan yang sangat penting pada suatu perusahaan yang memperlihatkan suatu ROE yang tinggi dan konsisten yang mengindikasikan:

1. Perusahaan mempunyai suatu keunggulan yang tahan lama dalam persaingan.

2. Investasi di dalam bentuk modal para pemegang saham akan tumbuh pada suatu tingkat pertumbuhan tahunan yang tinggi, sehingga akan mengarahkan kepada suatu harga saham yang tinggi di masa depan.

\section{Pengertian Net Profit Margin (NPM)}

Net Profit Margin (NPM) termasuk ke dalam rasio profitabilitas karena merupakan rasio perbandingan antara laba bersih dengan penjualan. Rasio ini menggambarkan laba bersih perusahaan yang dibandingkan dengan penjualan. Semakin tinggi NPM akan semakin baik operasi perusahaan begitu juga sebaliknya apabila semakin rendah NPM maka operasi perusahaan kurang baik.

Dan pengertian net profit margin menurut Joel G. Siegel dan Jae K. Shim (Irham Fahmi, 2013) adalah:

1. Margin laba bersih sama dengan laba bersih dibagi dengan penjualan bersih. Ini menunjukkan kestabilan kesatuan untuk menghasilkan perolehan pada tingkat penjualan khusus. Dengan memeriksa margin laba dan norma industri sebuah perusahaan pada tahun-tahun sebelumnya, kita dapat menilai efisiensi operasi dan strategi penetapan harga serta status persaingan perusahaan dengan perusahaan lain dalam industri tersebut.

2. Yang tinggi lebih disukai karena menunjukkan bahwa perusahaan mendapat hasil yang lebih baik yang melebihi harga pokok penjualan.

Berdasarkan uraian-uraian sebelumnya dan mengacu pada penelitian terdahulu, hipotesis penelitian dapat dirumuskan sebagai berikut:

$\mathrm{Ha}_{1}$ : Praktek good corporate governance berpengaruh positif terhadap kinerja perusahaan yang diukur dengan ROE.

$\mathrm{Ha}_{2}$ : Praktek good corporate governance berpengaruh positif terhadap kinerja perusahaan yang diukur dengan NPM.

\section{METODOLOGI PENELITIAN}

Penelitian ini akan dilaksanakan di Bursa Efek Indonesia dan The Indonesian Institute for Corporate Governance (IICG), sedangkan waktu penelitian ini dimulai dari bulan Oktober 2015 sampai dengan Januari 2016. Jenis penelitian yang digunakan adalah penelitian kausal (sebab-akibat). Penelitian kausal digunakan untuk mengetahui hubungan sebab-akibat dari variabel-variabel yang diteliti untuk menjawab pertanyaan penelitian (praktek GCG terhadap kinerja keuangan yaitu ROE dan NPM). Teknik pengumpulan data yang dilakukan dalam penelitian ini adalah purposive sampling. Metode pengumpulan data pada penelitian ini menggunakan data sekunder. Data penelitian berupa:

a. Data perusahaan yang termasuk dalam kelompok skor pemeringkatan Good corporate governance (CGPI) pada tahun 2009-2013.

b. Data-data perusahaan berupa data skor CGPI, besar nilai ROE dan NPM masing-masing perusahaan.

Populasi yang digunakan dalam penelitian ini adalah seluruh perusahaan yang masuk dalam skor pemeringkatan CGPI pada periode analisis tahun 2009-2013 yaitu sebanyak 64 
perusahaan. Sampel adalah sebagian dari jumlah dan karakteristik yang dimiliki oleh populasi tersebut, ataupun bagian kecil dari anggota populasi yang diambil menurut prosedur tertentu sehingga dapat mewakili populasinya.

Adapun kriteria data dalam pengambilan sampel pada penelitian ini adalah:

a. Perusahaan yang masuk dalam skor pemeringkatan (CGPI) dalam penerapan Good Corporate Governance (GCG) yang diperoleh dari The Indonesian Institute for Corporate Governance (IICG) dari tahun 2009-2013.

CGPI adalah program riset dan pemeringkatan praktik GCG Pada Perusahaan Publik, BUMN, BUMS, BUMD dan Lembaga Keuangan Syariah di Indonesia. CGPI menggunakan empat tahapan penilaian, yaitu Self Assessment, Dokumentasi, Makalah dan Observasi. Berdasarkan hasil tersebut diatas, maka peneliti menggunakan 9 sampel (9 perusahaan).

b. Perusahaan terdaftar di Bursa Efek Indonesia dari tahun 2009-2013, yang rutin menerbitkan data laporan keuangan tahunannya (annual report) ke Bursa Efek Indonesia secara berturut-turut.

c. Perusahaan sampel mempunyai laporan keuangan yang berakhir 31 Desember setiap tahunnya dan menggunakan rupiah sebagai mata uang pelaporan.

\section{Metode Analisis Data}

Analisis ini dilakukan dengan pengujian regresi sederhana, terlebih dahulu dilakukan pengujian asumsi klasik yang berguna untuk mengetahui apakah data yang digunakan telah memenuhi model regresi. Pengujian ini meliputi uji normalitas dengan metode KolmogorofSmirnov test, uji autokorelasi dengan perhitungan Durbin-Watson Test (DW Stat), uji heteroskedastisitas yang dilakukan dengan Spearman Correlation. Kemudian Uji Kelayakan Model (Goodness of Fit Test) meliputi Uji Koefisien Determinasi ( $\left.R^{2}\right)$.Selanjutnya melakukan uji masing-masing hipotesis (uji $t$ ).

\section{HASIL ANALISIS DAN PEMBAHASAN}

Sampel perusahaan yang akan diteliti berjumlah 9 perusahaan selama periode lima tahun. Dari hasil olahan data SPSS seluruh perusahaan telah memenuhi kriteria lulus uji prasyarat analisis (uji asumsi klasik) dan tidak ada masalah heteroskedastisitas jika diuji dengan menggunakan uji Glejser serta tidak ada masalah autokorelasi dengan perhitungan Durbin Watson Test (DW Test).

\section{Analisis Regresi Linier Sederhana}

Analisis regresi linier sederhana digunakan untuk mengetahui pengaruh satu variabel independen terhadap satu variabel dependen. Bentuk umum persamaan regresi linier sederhana sebagai berikut:

$$
\begin{aligned}
& \mathrm{Y} 1=\mathrm{a}+\mathrm{bX}+\mathrm{e}_{\mathrm{i}} \ldots \ldots \ldots \ldots \text {...... Persamaan } 1 \\
& \mathrm{Y} 2=\mathrm{a}+\mathrm{bX}+\mathrm{e}_{\mathrm{i}} \ldots \ldots \ldots \ldots . . . \text { Persamaan } 2
\end{aligned}
$$

Dimana:

Y1 : ROE 


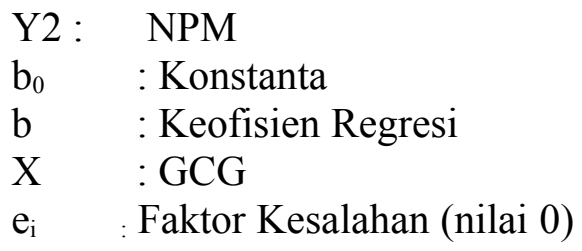

Hasil yang diperoleh setelah data diolah dengan bantuan program SPSS disajikan dalam tabel berikut ini:

\section{Analisis Regresi Linier Sederhana (Persamaan 1) \\ Coefficients $^{\text {a }}$}

\begin{tabular}{|c|c|c|c|c|c|}
\hline \multirow[b]{2}{*}{ Model } & \multicolumn{2}{|c|}{$\begin{array}{l}\text { Unstandardized } \\
\text { Coefficients }\end{array}$} & $\begin{array}{c}\text { Standardized } \\
\text { Coefficients } \\
\end{array}$ & \multirow[b]{2}{*}{$\mathrm{T}$} & \multirow[b]{2}{*}{ Sig. } \\
\hline & B & Std. Error & Beta & & \\
\hline (Constant) & -17.584 & 7.355 & & -2.391 & .021 \\
\hline Praktek GCG & .498 & .087 & .655 & 5.687 & .000 \\
\hline
\end{tabular}

a. Dependent Variable: ROE

Sumber : Data yang diolah, 2016

\section{Tabel}

Analisis Regresi Linier Sederhana (Persamaan 2)

Coefficients $^{\mathrm{a}}$

\begin{tabular}{|c|c|c|c|c|c|c|}
\hline \multirow{2}{*}{\multicolumn{2}{|c|}{ Model }} & \multicolumn{2}{|c|}{$\begin{array}{c}\text { Unstandardized } \\
\text { Coefficients } \\
\end{array}$} & \multirow{2}{*}{$\begin{array}{c}\text { Standardized } \\
\text { Coefficients }\end{array}$} & \multirow[b]{2}{*}{$\mathrm{T}$} & \multirow[b]{2}{*}{ Sig. } \\
\hline & & B & Std. Error & & & \\
\hline 1 & (Constant) & -15.423 & 6.710 & & -2.299 & .026 \\
\hline & $\begin{array}{l}\text { Praktek } \\
\text { GCG }\end{array}$ & .482 & .080 & .677 & 6.034 & .000 \\
\hline
\end{tabular}

a. Dependent Variable: NPM

Sumber : Data yang diolah, 2016

Persamaan regresinya sebagai berikut:

a. Persamaan 1

$$
\mathrm{Y}=-17,584+0,498 \mathrm{X}
$$

a) Konstanta sebesar -17,584; artinya jika $X$ nilainya adalah 0 , maka besarnya $Y$ nilainya negatif sebesar $-17,584$.

b) Koefisien regresi variabel $X$ sebesar 0,498; artinya setiap peningkatan $X$ sebesar 1 satuan, maka akan meningkatkan Y sebesar 0,498 satuan.

b. Persamaan 2

$$
\mathrm{Y}=-15,423+0,482 \mathrm{X}
$$

a) Konstanta sebesar -15,423; artinya jika Xnilainya adalah 0 , maka besarnya $\mathrm{Y}$ nilainya negarif sebesar $-15,423$.

b) Koefisien regresi variabel $\mathrm{X}$ sebesar 0,482 ; artinya setiap peningkatan $\mathrm{X}$ sebesar 1 satuan, maka akan meningkatkan Y sebesar 0,482 satuan.

Hasil Uji Signifikan Parsial (Uji t) 
Uji t pada regresi sederhana digunakan untuk menguji secara parsial apakah variabel independen berpengaruh terhadap variable dependen atau tidak.

Hasil uji t yang diperoleh disajikan sebagai berikut:

Tabel

Hasil uji t (Persamaan 1)

Coefficients $^{\mathrm{a}}$

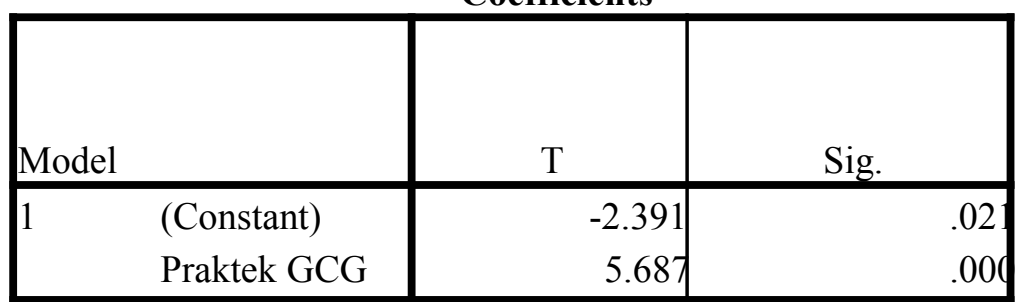

a. Dependent Variable: ROE

Sumber : Data yang diolah, 2016

Tabel

Hasil uji t (Persamaan 2)

Coefficients $^{\mathrm{a}}$

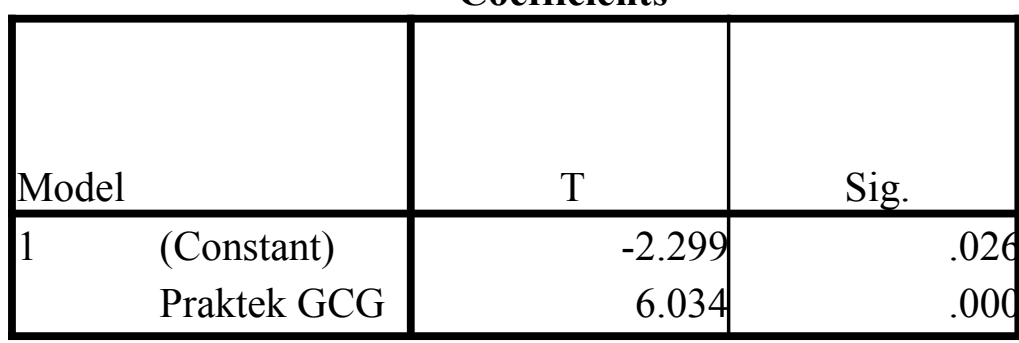

a. Dependent Variable: NPM

Sumber : Data yang diolah, 2016

a. Pengujian persamaan 1 (Praktek GCG terhadap ROE)

Langkah-langkah pengujian sebagai berikut:

1. Menentukan hipotesis nol dan hipotesis alternatif.

Ho $: \mathrm{b}=0 \quad$ Praktek Good corporate governance tidak

berpengaruh terhadap kinerja perusahaan yang

diukur dengan ROE.

Ha $: \mathrm{b} \neq 0 \quad$ Praktek Good corporate governance berpengaruh terhadap kinerja perusahaan yang diukur dengan ROE.

2. Menentukan $t_{\text {hitung }}$

Berdasarkan tabel di atas diperoleh $\mathrm{t}_{\text {hitung }}$ sebesar 5,687.

3. Menentukan $t_{\text {tabel }}$ dengan menggunakan tingkat signifikansi 0,05

Nilai $\mathrm{t}_{\text {tabel }}$ dapat dilihat pada tabel $\mathrm{t}$ statistik pada $\mathrm{df}=\mathrm{n}-2$ atau 45-2 $=43$ (k adalah jumlah variable independen). Dengan signifikansi 0,05, dan uji 2 sisi, diperoleh hasil $\mathrm{t}$ tabel $=2,017$.

4. Kriteria pengujian

a) Ho diterima bila $t_{\text {hitung }} \leq t_{\text {tabel. }}$

b) Ho ditolak bila $\mathrm{t}_{\text {hitung }}>\mathrm{t}_{\text {tabel. }}$.

5. Membandingkan $t_{\text {hitung }}$ dengan $t_{\text {tabel }}$ 
Nilai $t_{\text {hitung }}>t_{\text {tabel }}(5,687>2,017)$, maka Ho ditolak.

6. Membuat kesimpulan

Oleh karena nilai $\mathrm{t}_{\text {hitung }}>\mathrm{t}_{\text {tabel }}(5,687>2,017)$, maka Ho ditolak, artinya bahwa praktek good corporate governance berpengaruh terhadap kinerja perusahaan yang diukur dengan ROE.

Nilai t hitung positif, artinya praktek good corporate governance berpengaruh positif terhadap kinerja perusahaan yang diukur dengan ROE. Artinya bahwa semakin meningkatnya praktek GCG maka akan meningkatkan ROE.

b. Pengujian persamaan 2 (Praktek GCG terhadap NPM)

Langkah-langkah pengujian sebagai berikut:

1. Menentukan hipotesis nol dan hipotesis alternatif

Ho $: \mathrm{b}=0$ Praktek good corporate governance tidak berpengaruh terhadap kinerja perusahaan yang diukur dengan NPM.

$\mathrm{Ha}: \mathrm{b} \neq 0$ Praktek good corporate governance berpengaruh terhadap kinerja perusahaan yang diukur dengan NPM.

2. Menentukan $\mathrm{t}_{\text {hitung }}$

Berdasarkan tabel di atas diperoleh $t_{\text {hitung }}$ sebesar 6,034.

3. Menentukan $t_{\text {tabel }}$ dengan menggunakan tingkat signifikansi 0,05

Nilai $t$ tabel dapat dilihat pada tabel $t$ statistik pada $\mathrm{df}=\mathrm{n}-2$ atau 45-2 $=43$ ( $\mathrm{k}$ adalah jumlah variabele independen). Dengan signifikansi 0,05, dan uji 2 sisi, diperoleh hasil $t$ tabel $=2,017$.

4. Kriteria pengujian:

- Ho diterima bila $t_{\text {hitung }} \leq t_{\text {tabel. }}$.

- Ho ditolak bila $\mathrm{t}_{\text {hitung }}>\mathrm{t}_{\text {tabel. }}$

5. Membandingkan $t_{\text {hitung }}$ dengan $t_{\text {tabel }}$

Nilai $t_{\text {hitung }}>\mathrm{t}_{\text {tabel }}(6,034>2,017)$, maka Ho ditolak.

6. Membuat kesimpulan

Oleh karena nilai $\mathrm{t}_{\text {hitung }}>\mathrm{t}$ tabel $(6,034>2,017)$, maka Ho ditolak, artinya bahwa praktek good corporate governance berpengaruh terhadap kinerja perusahaan yang diukur dengan NPM.

Nilai t hitung positif, artinya praktek good corporate governance berpengaruh positif terhadap kinerja perusahaan yang diukur dengan NPM. Artinya bahwa semakin meningkat praktek GCG maka akan meningkatkan NPM.

\section{Analisis koefisien determinasi ( $R$ Square)}

Nilai koefisien determinasi menunjukkan seberapa besar prosentase model regresi mampu menjelaskan variabel dependen. Batas nilai $\mathrm{R}^{2}$ adalah $0 \leq \mathrm{R}^{2} \geq 1$ sehingga apabila $\mathrm{R}^{2}$ sama dengan nol (0) berarti variabel tidak bebas tidak dapat dijelaskan oleh variabel bebas secara serempak, sedangkan bila $\mathrm{R}^{2}$ sama dengan 1 berarti variabel bebas dapat menjelaskan variabel tidak bebas secara serempak.

Hasil analisis determinasi yang diperoleh setelah data diolah disajikan dalam tabel berikut ini: 
Tabel

Hasil Analisis Koefisien Determinasi pada Regresi 1

Model Summar $\mathbf{y}^{\mathbf{b}}$

\begin{tabular}{|l|r|r|r|r|r|}
\hline Model & $\mathrm{R}$ & R Square & $\begin{array}{c}\text { Adjusted R } \\
\text { Square }\end{array}$ & $\begin{array}{c}\text { Std. Error of } \\
\text { the Estimate }\end{array}$ & Durbin-Watson \\
\hline 1 & $.655^{\mathrm{a}}$ & .429 & .416 & 3.82909 & 2.338 \\
\hline
\end{tabular}

a. Predictors: (Constant), Praktek GCG

b. Dependent Variable: ROE

Sumber: Data yang diolah,

2016

\section{Tabel}

Hasil Analisis Koefisien Determinasi pada Regresi 2

\begin{tabular}{|l|r|r|r|r|r|}
\hline Model & R & R Square & $\begin{array}{c}\text { Adjusted R } \\
\text { Square }\end{array}$ & $\begin{array}{c}\text { Std. Error of } \\
\text { the Estimate }\end{array}$ & Durbin-Watson \\
\hline 1 & $.677^{\mathrm{a}}$ & .458 & .446 & 3.49291 & 1.745 \\
\hline
\end{tabular}

a. Predictors: (Constant), Praktek GCG

b. Dependent Variable: NPM

Sumber: Data yang diolah, 2016

Berdasarkan tabel di atas diperoleh kesimpulan sebagai berikut:

(1) Untuk persamaan 1, nilai $\mathrm{R}^{2}$ sebesar 0,429 (42,9\%). Hal ini menunjukkan bahwa variasi variabel independen yang digunakan dalam model (praktek GCG) mampu menjelaskan sebesar $42,9 \%$ variasi variabel ROE, dan sisanya dijelaskan oleh variabel lain yang tidak dimasukkan dalam model penelitian ini.

(2) Untuk persamaan 2, nilai $\mathrm{R}^{2}$ sebesar 0,458 (45,8\%). Hal ini menunjukkan bahwa variasi variabel independen yang digunakan dalam model (praktek GCG) mampu menjelaskan sebesar 45,8\% variasi variabel NPM, dan sisanya dijelaskan oleh variabel lain yang tidak dimasukkan dalam model penelitian ini.

\section{KESIMPULAN}

Berdasarkan hasil penelitian mengenai "Pengaruh Praktek Good Corporate Governance terhadap Kinerja Keuangan Perusahaan yang Masuk dalam Pemeringkatan Corporate Governance Perception Index (CGPI)" yang dilakukan dengan metode purposive sampling dan data penelitian berupa perusahaan yang masuk dalam kelompok skor pemeringkatan good corporate governance yaitu CGPI serta ROE dan NPM masing-masing perusahaan yang diambil dari annual report di Bursa Efek Indonesia serta menggunakan metode analisis data dengan metode regresi linear sederhana, dapat diambil kesimpulan sebagai berikut:

1. Praktek good corporate governance berpengaruh terhadap kinerja perusahaan yang diukur dengan ROE. Hal ini ditunjukkan oleh uji t yang didapat nilai $t_{\text {hitung }}>t_{\text {tabel }}(5,687>2,017)$, sehingga Ho ditolak. Nilai t hitung positif, artinya praktek good corporate governance berpengaruh positif terhadap kinerja perusahaan yang diukur dengan ROE. Artinya bahwa semakin meningkatnya praktek GCG maka akan semakin meningkatkan ROE.

2. Praktek good corporate governance berpengaruh terhadap kinerja perusahaan yang diukur dengan NPM. Hal ini ditunjukkan oleh uji t yang didapat nilai $t_{\text {hitung }}>t_{\text {tabel }}(6,034>2,017)$, sehingga Ho ditolak. Nilai t hitung positif, artinya praktek good corporate governance 
berpengaruh positif terhadap kinerja perusahaan yang diukur dengan NPM. Artinya bahwa semakin meningkatnya praktek GCG maka akan semakin meningkatkan NPM.

Hasil penelitian ini bertolak belakang penelitian yang dilakukan oleh Gabriela Cyntya Windah yang menunjukkan bahwa tidak adanya pengaruh signifikan antara variabel independen GCG terhadap kinerja keuangan perusahaan. Namun, hasil penelitian ini sejalan dengan hasil penelitian yang dilakukan oleh Carina Hermanda dan Like Monisa Wati yang menyatakan bahwa praktek GCG memberikan pengaruh kepada kinerja keuangan perusahaan sesuai dengan teori yang ada. Maka dapat disimpulkan bahwa dengan diterapkannya prinsipprinsip GCG dalam perusahaan, maka pihak-pihak yang terkait di perusahaan memiliki tanggung jawab yang jelas sesuai dengan peraturan yang berlaku, sehingga dapat mendorong pengelolaan yang lebih demokratis (karena melibatkan partisipasi banyak kepentingan), lebih accountable (karena ada sistem yang kana meminta pertanggungjawabkan atas setiap tindakan), lebih transparan serta akan meningkatkan keyakinan bahwa perusahaan dan organisasi lainnya dapat menyumbangkan manfaat tersebut dalam jangka panjang, dalam hal ini, tentu saja kinerja keuangan perusahaan yaitu Return of Equity (ROE) dan Net Profit Margin (NPM) akan meningkat seiring dengan berjalannya kegiatan perusahaan.

\section{SARAN}

Saran yang dapat diberikan oleh peneliti dari hasil penelitian yang telah dilakukan agar bisa dijadikan masukan adalah sebagai berikut:

1. Untuk penelitian selanjutnya dapat menggunakan sampel perusahaan yang lebih banyak, misal sebanyak 30 perusahaan, sehingga hasil penelitian akan lebih valid dan populasi lebih luas.

2. Untuk penelitian selanjutnya dapat menggunakan variabel yang lebih banyak lagi, sehingga hasil penelitian akan lebih valid.

3. Selain itu, peneliti selanjutnya dapat menggunakan proksi lain untuk menghitung nilai kinerja keuangan dengan menggunakan ROA, EPS, Tobin's Q serta alat ukur lainnya yang digunakan dalam rasio keuangan untuk melihat kinerja keuangan perusahaan.

\section{DAFTAR PUSTAKA}

Alhusin, Syahri. 2003. "Aplikasi Statistik Praktis dengan Menggunakan SPSS 10 for

Windows". Edisi Kedua. Yogyakarta: Graha Ilmu.

Arafat, Wilson. 2008. "How to Implement Good corporate governance". Jakarta:

Skyrocketing Publisher.

Arikunto, Suharsimi. 2002. "Prosedur Penelitian: Suatu Pendekatan Praktek", Edisi Revisi V. Jakarta: PT Rineka Cipta.

Dani Riandi dan Hasan Sakti Siregar. 2011. "Pengaruh Penerapan Good corporate governance terhadap ROA, NPM dan EPS pada Perusahaan yang Terdaftar di CGPI'. Jurnal Ekonomi Vol. 14 Nomor 13.

Daniri, Achmad. 2005. "Good corporate governance: Konsep dan Penerapannya dalam Konteks Indonesia". Jakarta: PT Triexs Trimacindo.

Effendi, Muh. Arief. 2009 "The Power of Good corporate governance: Teori dan

Implementasi”. Jakarta: Salemba Empat.

Ghazali, Imam. 2005. Aplikasi Analisis Multivariat Dengan Menggunakan Program SPSS. Universitas Gajah Mada Press: Yogyakarta.

Ghazali, Imam. 2011. Aplikasi Analisis Multivariat Dengan Program IBM SPSS 19. Cetakan kelima. Universitas Diponegoro: Yogyakarta. 
Hanafi, M. M. 2004. "Manajemen Keuangan". Yogyakarta: BPFE. http://peluangusahamakro.blogspot.co.id/2013/09/pengertian-corporate-governancedan 15.html (akses dibuka pada tgl 13/10/2015).

Keputusan Menteri Badan Usaha Milik Negara, Nomor: KEP-117/MMBU/ 2002 tentang "Penerapan Praktek Good corporate governance Pada Badan Usaha Milik Negara (BUMN)".

Kusumawati, Dwi Novi dan Bambang Riyanto LS. 2005. Corporate Governance dan Kinerja: Analisis Compliance Reporting dan Struktur Dewan terhadap Kinerja. Simposium Nasional Akuntansi (SNA) VIII Solo.

Martono, Nanang. 2010. Metode Penelitian Kuantitatif: Analisis Isi dan Analisis Data Sekunder. Jakarta: PT. RajaGrafindo Persada.

Priyatno, Duwi. 2010. "5 Jam Belajar Olah Data Dengan SPSS 17”. Cetakan Kedua, Yogyakarta: ANDI.

Sedarmayanti. 2007. Governance dan Good corporate governance. (Edisi Ketiga). Bandung: Penerbit Mandar Maju.

Samsul, Mohammad. 2006. Pasar Modal dan Manajemen Portofolio. Surabaya: Erlangga.

Santoso, Singgih. 2001. Buku Latihan SPSS Statistik Parametrik. PT.ELEK Jakarta: Media Komputindo.

Sawir, Agnes, 2005. Analisis Kinerja Keuangan dan Perencanaan Keuangan Perusahaan, Jakarta: PT Gramedia Pustaka Utama.

Sayidah, Nur. 2007. "Pengaruh Kualitas Corporate Governance terhadap Kinerja Perusahaan Publik (Studi kasus 10 besar CGPI tahun 2003, 2004, 2005)". Jurnal Akuntansi dan Auditing Indonesia, Vol 11. hlm. 4.

Subramanyam, K. R., \& Wild, J. J. 2002. Financial Statement Analysis (10 ed.). (S. Empat, Ed., \& D. Yanti, Trans.) Jakarta: Salemba Empat.

Sugiyono. 2007. "Metode Penelitian Bisnis". Bandung: CV. Alfabeta.

Suprayitno, G., S. Yasni, A. Susanty, R.J. Arsjah, L.H. Kusumah, A. Wicaksono, Z. Abidin, M. Susandy, S. Olivia Tito, A. Riyadi, 2010, Laporan Hasil Riset \& Pemeringkatan Corporate Governance Perception Index 2009: GCG Sebagai Budaya, IICG, Jakarta.

Suprayitno, G., S. Yasni, A. Susanty, L.H. Kusumah, Z. Abidin, M. Susandy, S. Olivia Tito, A. Riyadi, E. Kusnawijaya, R. Poerwanto. 2011. Laporan Hasil Riset \& Pemeringkatan Corporate Governance Perception Index 2010: GCG dalam Perspektif Etika, IICG, Jakarta.

Suprayitno, G., S. Yasni, A. Susanty, L.H. Kusumah, Z. Abidin, M. Susandy, S. Olivia Tito, A. Riyadi, E. Kusnawijaya, R. Poerwanto, T. Aryati, Z. Naimah, R. Januarita. 2012. Laporan Hasil Riset \& Pemeringkatan Corporate Governance Perception Index 2011: GCG dalam Perspektif Risiko, IICG, Jakarta.

Suprayitno, G., S. Yasni, A. Susanty, L.H. Kusumah, Z. Abidin, M. Susandy, S. Olivia Tito, A. Riyadi, E. Kusnawijaya, R. Poerwanto, T. Aryati, Z. Naimah, R. Januarita, Henni Gusfa. 2011. Laporan Hasil Riset \& Pemeringkatan Corporate Governance Perception Index 2012: GCG dalam Perspektif Manajemen Pengetahuan, IICG, Jakarta.

Suprayitno, G., S. Yasni, A. Susanty, L.H. Kusumah, Z. Abidin, M. Susandy, S. Olivia Tito, E. Kusnawijaya, T. Aryati, Z. Naimah, R. Januarita, Henni Gusfa, N. Fajriya. 2012. Laporan Hasil Riset \& Pemeringkatan Corporate Governance Perception Index 2013: GCG dalam Perspektif Organisasi Pembelajar, IICG, Jakarta.

Surat Keputusan Menteri Negara/Kepala Badan Penanaman Modal dan Pembinaan BUMN No. 23/M-PM.PBUMN/2000 tentang "Pengembangan Praktek GCG dalam Perusahaan Perseroan (Persero)". 
Sutrisno, 2003. Manajemen Keuangan (Teori, Konsep, dan Aplikasi). Yogyakarta: BPFE.

Syamsuddin, Lukman. 2004. "Manajemen Keuangan Perusahaan”. Jakarta: PT. RajaGrafindo Persada.

Tambun. 2007. Menilai Harga Wajar Saham. Jakarta: PT. Gramedia Pustaka Utama.

Tjager. IN., Alijoyo, F.A., Djemat, H.R, dan Soembodo, B. 2003. "Corporate Governance: Tantangan dan Kesempatan bagi Komunitas Bisnis Indonesia, Serial Mastering Good Coprorate Governance". Jakarta: Prenhanllindo.

Wati, Like Monisa. 2012. "Pengaruh Praktek Good corporate governance Terhadap Kinerja Keuangan Perusahaan di Bursa Efek Indonesia”. Jurnal Manajemen, Vol. 1 Nomor 1.

www.iicg.org/ Skor pemeringkatan (CGPI) dalam penerapan Good corporate governance (GCG) yang diperoleh dari The Indonesian Institute for Corporate Governance (IICG).

www.idx.co.id/ Pasar Modal Saham Indonesia 